Open Access Full Text Article

\title{
Barriers to good glycemic control levels and adherence to diabetes management plan in adults with Type-2 diabetes in Jordan: a literature review
}

This article was published in the following Dove Press journal:

Patient Preference and Adherence

\section{Amer Al-Sahouri \\ Joy Merrell \\ Sherrill Snelgrove}

Department of Public Health, Policy and Social Sciences, Swansea University,

Swansea, UK
Correspondence: Amer Al-Sahouri Department of Public Health, Policy and Social Sciences, Swansea University, 3I Bartley Terrace, Plasmarl, Swansea SA6 $8 \mathrm{LN}$, Wales, UK

Email amersahouri@yahoo.com

\begin{abstract}
Poorly controlled Type-2 diabetes is considered a significant public health problem and associated with adverse outcomes in Jordan. This review focuses on barriers to good glycemic control levels and adherence to diabetes management plan in adults with Type- 2 diabetes in Jordan. The aim was to identify the extent of Type- 2 diabetes and the influence of knowledge, perceptions and sociocultural factors on adherence to the diabetes management plan. Thirty-two studies were included in the literature review. The high prevalence rate of poorly controlled Type- 2 diabetes is associated with many negative consequences among patients in Jordan. Despite the publication of research findings that have shown the importance of adherence to diet, physical activity, medications, monitoring blood glucose and foot care, the level of adherence is still unsatisfactory among patients in Jordan. This review also identified that social, cultural and religious factors influence diabetes management. These factors highlighted the overwhelming influence of sociocultural factors and lifestyles as determinants of patients' health and health behaviors. For example, the influence of family, friends and culture on herbal use and food preferences that patients make on a daily basis and during social gatherings. A holistic approach incorporating patient-centered care could usefully be incorporated into educational programs to improve the understanding of patients' health and information needs. The importance of factors beyond the individual level in terms of social, cultural, organizational and policy influences such as food habits, religious beliefs and lack of continuity of care were identified as key factors which influence adherence to the diabetes management plan. Recognition of multiple determinants of patients' health among health care professionals may expand the scope of interventions to seek to modify social norms and values and improve patient outcomes.
\end{abstract}

Keywords: poorly controlled Type-2 diabetes, preferences, cultural factors, lifestyle, behaviors, determinants

\section{Introduction}

Diabetes mellitus is a significant health problem in the Middle East region. The prevalence rate of diabetes is expected to increase from 39 million people in 2017 to 82 million people in 2045, and it is considered the second highest prevalence among the world regions after North America and the Caribbean. ${ }^{1}$ In 2016, 13.1\% of the population in Jordan is reported to have diabetes. ${ }^{2}$

During the last 30 years, people in Jordan have experienced behavioral and lifestyle changes. ${ }^{3}$ These changes have led to a rise in the prevalence of all types of 
diabetes in Jordan and also an increase in the risk factors associated with diabetes such as poor quality nutrition, more consumption of fast food, low intake of fruits and vegetables, reduced physical activity, obesity, smoking and poor awareness of healthy weight among people in Jordan. $^{3-5}$ Additionally, inviting guests for sharing meals which include high-calorie content is considered as a highly valued socio-cultural habit in the Arab World and may contribute to the high prevalence of diabetes in Jordan. $^{3}$ Lack of knowledge about healthy behaviors and the role of social activities has also contributed to a sedentary lifestyle in Jordan. ${ }^{6}$

According to the World Health Organization statistics, in 2016, 21\% of male Jordanians and 35.6\% of female Jordanians were considered obese. ${ }^{2}$ The prevalence rate of overweight is also high at $58.9 \%$ for males and $66 \%$ for females in Jordan in $2016 .{ }^{2}$ Overweight and obesity are defined as abnormal or excessive fat accumulation that presents a risk to health. A crude population measure of obesity is the body mass index (BMI), a person's weight (in kilograms) divided by the square of his or her height (in metres). A person with a BMI of 30 or more is generally considered obese. A person with a BMI equal to or more than 25 is considered overweight. ${ }^{7}$ Lack of knowledge about healthy behaviors, high energy dense diet, the role of social activities that are associated with consuming a high-calorie dense food, sedentary lifestyle and physical inactivity. ${ }^{12}$ As populations in Jordan become more urbanized, and as lifestyles shift towards increased physical inactivity and increased food consumption, the prevalence of obesity and overweight is expected to rise. ${ }^{8}$ The prevalence rates of overweight and obesity among children and adolescents in Jordan were $21.6 \%$ and $10.2 \%$ in 2012 , respectively,. ${ }^{23}$ Therefore, there is a need for more public health campaigns to reduce the burden of obesity as a risk factor for developing Type-2 diabetes mellitus (T2DM) in the future.

Lifestyle changes and adherence to diabetes treatment plans are influenced by patients' perceptions, health beliefs and their attitudes towards T2DM. ${ }^{9}$ Cultural, religious, social and personal factors may influence patients' adherence to a healthy diet in Jordan. ${ }^{6}$

The literature would suggest that patients with diabetes also believe that adherence to medications was more important than other diabetes management behaviors. Previous studies in Jordan reported that people with diabetes showed more adherence to medications than other management behaviors. ${ }^{10,11}$
This review is thematically organized into four themes which were derived from reviewing the literature. The first theme discusses the extent of T2DM and significant diabetes related-complications in Jordan. The second theme addresses diabetes self-management behaviors. The third theme focuses on the knowledge, perceptions and attitudes of patients regarding their condition. The fourth theme reports on the literature regarding complementary medicine and the reasons for herbal use among patients.

The aim of this review was to identify the extent of T2DM and the influence of knowledge, perceptions and sociocultural factors on adherence to the diabetes management plan in Jordan. Also, this review will be used to inform policy and practice and specifically will be used to inform the development of an educational package for patients with T2DM. To date, there are no published literature reviews identified from Jordan regarding barriers to good glycemic control levels and adherence to diabetes management plan in adults with T2DM.

\section{Methods}

The literature review began in October 2015 when I enrolled in my $\mathrm{PhD}$ studies and has been ongoing with regular updating and reviewing of the literature to ensure up-to-date information has been included. The review used a narrative approach and synthesized the evidence from research and literature reviews published between 2006 and 2019. The literature search was conducted in English and all the reviewed studies were published in English. All studies wherein adherence to diabetes management behaviors and/or lifestyle measures among adults with diabetes or T2DM in Jordan were eligible for inclusion. In addition, studies that focused on the knowledge, attitudes and perceptions of patients with diabetes and factors affecting adherence to their treatment plans were included. The inclusion criteria required that the study was conducted in Jordan and that the study population was adults (aged 18 years and older) with diabetes or T2DM. The studies retrieved from the literature searches were carefully evaluated and analyzed to identify all studies meeting the inclusion criteria for the literature review. The quality of each study was assessed using checklists adapted from the Critical Appraisal Skills Program (CASP). CASP tools were used to analyze, critique and evaluate the published quantitative and qualitative literature. ${ }^{13}$

This literature review aimed to identify the literature regarding factors associated with poorly controlled T2DM. The search strategy used keywords related to the aim of 
this study. During this research study, more themes and keywords emerged which resulted in revising, expanding and adding more keywords to the search strategy. Multiple search strategies were adopted. First, all studies related to the aim of this study among adults with diabetes in Jordan were eligible for inclusion. Second, the research topic was divided into parts, concepts and terms. Third, different forms were used of keywords for each concept such as synonyms, different terminologies, alternative words and alternative spelling.

Search terms were (diabetes or Type-2 diabetes AND adherence or compliance AND medications use or diet or physical activity or blood monitoring or foot care AND Jordan), with or without the combination of the search terms (health beliefs, lifestyle, management behaviors, patient behavior, insulin). Diabetes or Type-2 diabetes AND knowledge or perception or attitudes AND Jordan. Studies that reported diabetes complications were searched using the search terms (complications or erectile dysfunction or metabolic syndrome or retinopathy AND diabetes). Also, studies that discussed socio-cultural factors and diabetes were searched using the search terms (cultural norms or religion or social habits or complementary and alternative medicine or herbs AND diabetes).

The key electronic databases used for literature searching included MEDLINE, Google, Google Scholar, Swansea University IFind research, Web of Science, PsycInfo, PubMed, International Bibliography of the Social Sciences (IBSS) and Applied Social Sciences Index and Abstracts (ASSIA). Research articles, abstracts, literature reviews, the reference list of included studies, reports and documents related to the research subject were reviewed carefully.

The literature search yielded 667 studies in total. Titles and abstracts were examined to identify eligibility for full screening. Studies were screened by title as the first step, then abstract. Sixty-six studies were eligible for full-text screening. Thirty-two studies were included in this literature analysis (Figure 1). Also, a full description of the studies included in the literature review is provided in Table S1.

A total of 635 studies were excluded from the review based on the subsequent sifting process, and inclusion criteria set out previously. Exclusion reasons varied, for example, studies were not conducted in Jordan, having irrelevant aims, including participants who are not diagnosed with diabetes or chronic conditions, and including patients with Type-1 diabetes only were excluded. Studies were also excluded due to unavailability of full access to the study and the inclusion of pregnant women with gestational diabetes. Studies on adherence to medications other than oral hypoglycemic tablets and/or insulin were also excluded.

\section{Results}

A total of 32 studies were eligible and included in this review focusing on the barriers to good glycemic control and adherence to diabetes management plan in adults with T2DM in Jordan. Of these 32 studies, 13 discussed issues related to Type 1 diabetes and T2DM, ${ }^{8,14-16,31,35,42,43,53-57,71}$ while 13 focused on T2DM only. ${ }^{10,11,17,19,21,25,29,33,34,44,45,48,56}$ Four of the studies addressed other long-term diseases alongside diabetes, ${ }^{26,50,51,70}$ and two studies focused on lifestyle issues and diabetes-risk factors. ${ }^{18,41}$ The settings of the research studies were primary health care centers $(n=3)$, hospitals $(\mathrm{n}=13)$, diabetes center $(\mathrm{n}=1)$, The National Diabetes Centre $(n=10)$, households $(n=4)$, and both hospitals and primary care centers $(\mathrm{n}=1)$. The sample sizes of the reviewed studies ranged from 49 to 3,196 participants for the quantitative studies and from 7 to 38 participants for the qualitative studies (Table S1).

The literature search and review identified that the cross-sectional survey is the most popular research design in the published articles and papers related to diabetes in Jordan $(n=27)$. Only two studies applied qualitative methods (focus groups and interviews). ${ }^{56,57}$ One study applied pre/post randomized trial, ${ }^{43}$ and one study was a prospective cohort study. ${ }^{54}$ All were empirical studies and no published literature reviews were identified from Jordan about diabetes.

\section{The extent of T2DM and its complications in Jordan}

Chronic conditions are considered the leading cause of mortality in Jordan. ${ }^{22}$ Jordan has witnessed demographic changes such as increasing life expectancy rates and an epidemiological transition as the burden of communicable diseases has reduced compared with the high prevalence rates of non-communicable conditions, namely cardiovascular diseases and diabetes. ${ }^{12}$ These changes in the Jordanian healthcare profile have an impact on the public health policies and priorities in Jordan to shift the focus more towards the non-communicable conditions. Diabetes mellitus was the third leading cause of mortality after ischemic heart disease and stroke in Jordan in $2015 .^{2}$ 


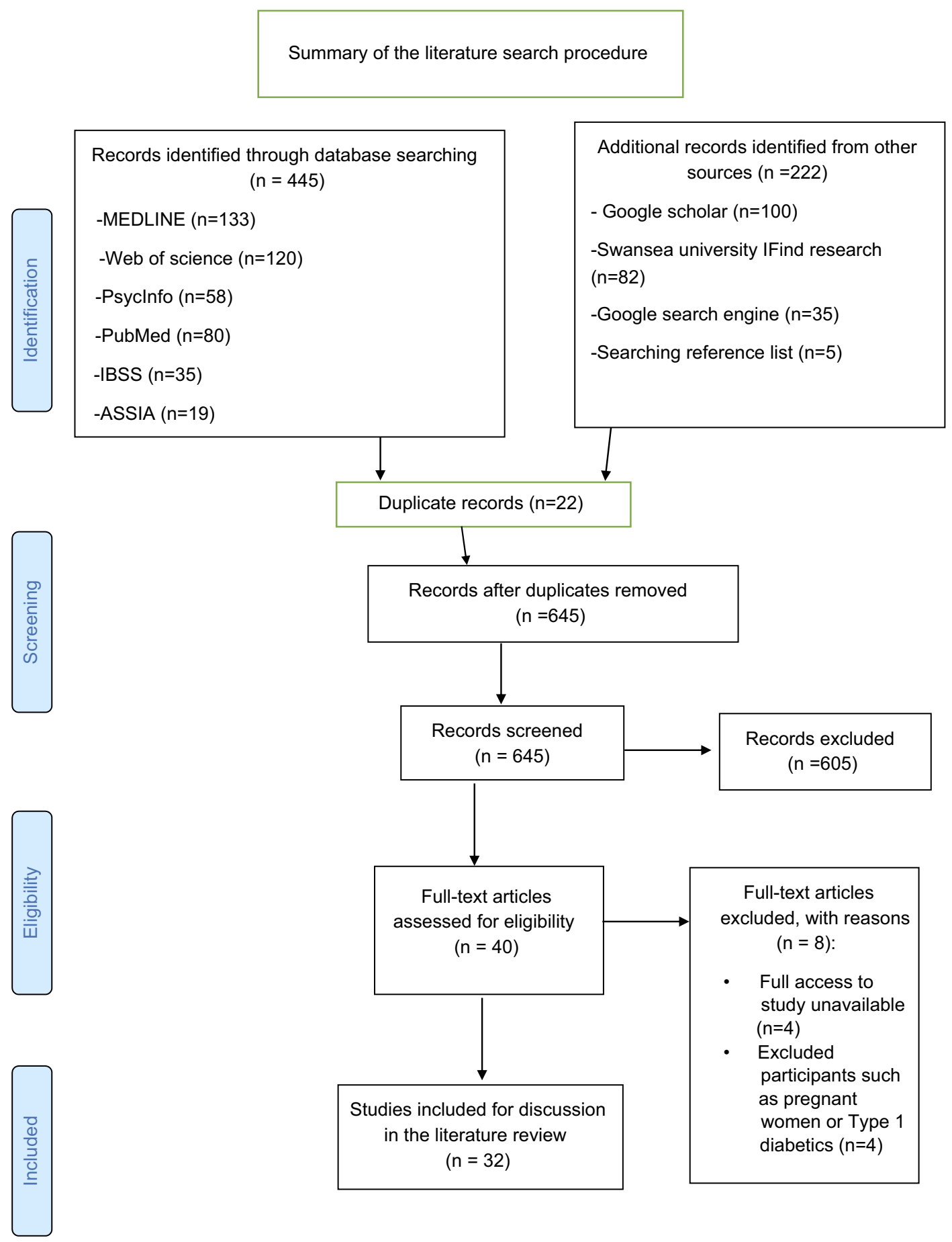

Figure I PRISMA flow diagram showing the selection process of the included studies in the literature review.

A review of the epidemiological literature in Jordan and international health organizations showed that the high prevalence rate of diabetes among Jordanians is higher than the prevalence rate of diabetes globally $(8.5 \%) .{ }^{63}$ Reported estimations of the prevalence of diabetes in Jordan varied from $9 \%$ to $17.1 \%{ }^{18}$ For instance, the prevalence rate of diabetes in Jordan increased from 13\% in $1998^{24}$ to $17.1 \%$ in $2008 .{ }^{18}$ Based on a report provided by the International Diabetes Federation in 2017, it is estimated that the prevalence rates of diabetes in Jordan and its neighboring Arab countries such as Saudi Arabia, Qatar and the United Arab Emirates (UAE) were 9.5\%, 
$18.5 \%, 14.1 \%$ and $15.6 \%$, respectively,. ${ }^{1}$ The prevalence rates of diabetes, overweight and obesity in Jordan were also reported as $13.1 \%, 62.3 \%$ and $28.1 \%$, respectively. ${ }^{2}$

Obesity and overweight are the main risk factors for developing diabetes and its complications. ${ }^{63}$ Overweight and obesity are defined as abnormal or excessive fat accumulation that presents a risk to health. A person with a BMI of 30 or more is generally considered obese. A person with a BMI equal to or more than 25 is considered overweight. ${ }^{7}$ The high prevalence of diabetes and obesity coupled with high levels of undiagnosed conditions and smoking, particularly among men, indicate the need for immediate implementation of programs to prevent and control chronic conditions and their risk factors in Jordan. ${ }^{8,12}$ Patients with T2DM rely on using cars and other methods of transportation instead of walking even for short distances. ${ }^{30}$ These features of a sedentary lifestyle besides physical inactivity and changes in dietary habits contributed to the increase in the prevalence of obesity among patients with T2DM in Jordan. ${ }^{10,18}$ For example, a cross-sectional study reported that the prevalence of obesity was $67.2 \%$ among 195 diabetic subjects in Jordan. ${ }^{18}$ The high prevalence of obesity among patients with T2DM was also reported by another cross-sectional study that found $69.5 \%$ of 532 participants were classified as obese. ${ }^{10}$

In most people with T2DM, there is a multiple set of risk factors that commonly appear together, forming the Metabolic Syndrome. ${ }^{38}$ Metabolic syndrome is associated with overweight or obesity, a lack of physical activity and insulin resistance which is a key feature of $\mathrm{T}_{2} \mathrm{DM}{ }^{38}$ Metabolic syndrome (MS) is a group of cardiovascular risk factors including diabetes, raised fasting blood glucose, high blood pressure, abdominal obesity and high cholesterol. ${ }^{1}$ People with metabolic syndrome have a fivefold greater risk of developing T2DM. ${ }^{38}$ The prevalence rate of metabolic syndrome in Jordan increased from $36.3 \%$ in $2008^{27}$ to $37.4 \%$ in 2010 and $51 \%$ in $2015 .^{20,26}$

Previous studies reported that the high prevalence rate of diabetes is associated with many negative consequences such as sexual dysfunction, diabetic neuropathy and diabetic retinopathy. ${ }^{14,15,20,25,26}$ Conducting studies regarding the sexual life of patients with diabetes may face challenges. For instance, patients may feel embarrassed when they talk about their sexuality or sexual difficulties in front of health care providers. ${ }^{14}$ Erectile dysfunction is one of the common complications of diabetes among men, and it is a sign of cardiovascular diseases and premature mortality. ${ }^{28}$ There is a scarcity of published studies regarding sexual function among patients with diabetes in Jordan.

However, one cross-sectional survey was conducted to identify the prevalence rate of erectile dysfunction among 988 patients with diabetes. ${ }^{25}$ The mean age of participants was 57 years. Structured interviews were conducted and based on the International Index of Erectile Function to assess erectile function, intercourse satisfaction, orgasmic function, sexual desire and overall satisfaction. As high as $62 \%$ were found to have erectile dysfunction and $75 \%$ $(\mathrm{n}=741)$ had a HbA1c $>7 \%$. The high prevalence of erectile dysfunction $(62 \%)$ was due to the high number of poorly controlled cases and the older age of participants. ${ }^{25}$

A cross-sectional study reported that female sexual dysfunction was higher in female patients with diabetes than females without diabetes. ${ }^{14}$ The Female Sexual Function Index questionnaire was used to collect data about desire, arousal, lubrication, orgasm, satisfaction and pain from 613 female patients with all types of diabetes and 524 women without diabetes. ${ }^{14}$

Diabetic retinopathy is a common microvascular complication among patients with diabetes due to unstable blood glucose levels and a longer duration of diabetes. ${ }^{28}$ Prevalence of diabetic retinopathy in Jordan is high, 34.1\% in 2008 compared with $48.4 \%$ in $2015 .^{15,16,29}$ In a crosssectional study of 1961 diabetic patients living in Jordan, $64.1 \%(n=1257)$ were found to have one type of diabetic retinopathy. ${ }^{15}$ Another cross-sectional study reported that $34.1 \%$ of a sample of 1000 patients with T2DM had diabetic retinopathy. As high as $77.5 \%$ of the study participants were found to have a $\mathrm{HbA} 1 \mathrm{c} \geq 7 \%$, the mean age was 57.8 years, and the mean duration of disease was 9.6 years. ${ }^{16}$ Another cross-sectional study aimed to identify the prevalence of blindness, visual impairment, diabetes and diabetic retinopathy in north Jordan. A total of 3638 participants were examined. Untreated cataract and diabetic retinopathy were the major causes of blindness, accounting for $46.7 \%$ and $33.2 \%$ of total blindness cases, respectively. $^{29}$ The prevalence of diabetes mellitus was $28.6 \%$ among the study participants. The prevalence of diabetic retinopathy among patients with diabetes was $48.4 \%{ }^{29}$ The high number of poorly controlled cases, the old ages of participants and the long duration of T2DM might explain the high prevalence of diabetic retinopathy among the samples in these studies. By contrast, another cross-sectional survey reported a lower prevalence of diabetic retinopathy of $7.9 \%$ amongst a randomly selected sample of 127 people with T2DM in Jordan. ${ }^{44}$ 
After comparison with the other published studies in Jordan, this lower prevalence rate may be explained by the differences within the samples with the participants in the latter study having only had T2DM for less than six months, and the mean age was $49.7 \pm 10$ years. Longer duration of diabetes and an older age are the main risk factors for the development of diabetic retinopathy. ${ }^{28}$

Over recent years, Jordan has witnessed not only the high prevalence of T2DM but also an increase in the number of poorly controlled T2DM cases. Several studies have been conducted in Jordan which showed the prevalence of poorly controlled diabetes among patients with diabetes, was high. ${ }^{14,31,32}$ Other authors aimed to conduct their studies including only patients with T2DM. These studies reported that the prevalence rate of poorly controlled T2DM was also high ranging from $43.9 \%$ to $78.2 \% .^{10,11,18,21,33,34}$

A cross-sectional study identified 195 participants who had T2DM, of whom 79 (54\%) were poorly controlled cases. Unsatisfactory glycemic control was defined in the study as a HbA1c $>7.5 \% .{ }^{18}$ A longer duration of T2DM and type of treatment have been found to be associated with poor glycemic control levels in Jordan. ${ }^{33}$ A cross-sectional study also reported that poor adherence to self-care management behaviors, negative attitudes toward diabetes and longer duration of T2DM were associated with poor glycemic control levels among people with T2DM. ${ }^{10} 65.1 \%$ of participants $(n=917)$ were identified as having poorly controlled T2DM with a $\mathrm{HbA} 1 \mathrm{c} \geq 7 \%{ }^{10}$

\section{Diabetes self-management behaviors Diet}

Poor diet is one of the modifiable risk factors in addressing the increase of prevalence of T2DM among people living in Jordan. There have been many studies which have explored the diet among patients with diabetes in Jordan. 8,10,31,33-35

A review of the literature in Jordan showed that most of the patients with diabetes did not follow a healthy, balanced diet as recommended by the dietitian and being reluctant to follow the diet was associated with poorly controlled diabetes. ${ }^{10,31}$ Cultural, religious, social and personal factors may influence patients' adherence to a healthy diet in Jordan. ${ }^{6}$ Furthermore, since there is a lack of national dietary guidelines for patients with diabetes in Jordan, ${ }^{34}$ patients with T2DM may be unaware of what constitutes a healthy diet. The current protocol of treatment and self-care recommendations for patients with T2DM in Jordan were not identified in the article.

A cross-sectional study was conducted to identify the factors associated with poorly controlled T2DM in Jordan. The study findings reported that poor adherence to the recommended diabetic diet was associated with poor glycemic control levels among patients with T2DM and $81.4 \%$ of the 917 participants did not follow the diabetic diet. $^{10}$ This result is similar to another cross-sectional study with a sample size of 649 patients with diabetes in Jordan which showed $64.7 \%$ of the participants did not follow the diabetic diet and $70.9 \%$ of the participants were poorly controlled. ${ }^{31}$ Following the recommended diabetic diet in both studies referred to people with diabetes who had followed the diabetic diet as recommended by a dietitian $\geq 3$ days in the last 7 days.

The human body needs fats that should principally come from monounsaturated and polyunsaturated sources, for instance, fish oils, avocado oil and olive oil. ${ }^{28}$ Olive oil is a key component of the Jordanian daily diet due to cultural and religious beliefs. ${ }^{34}$ Olive oil is a good source of monounsaturated fats which are considered "good" fats, which can reduce the levels of cholesterol and can improve insulin sensitivity among people with diabetes. ${ }^{36}$ A high intake of monounsaturated fats was attributed to olive oil consumption among patients with diabetes in Jordan. $^{34}$ One study conducted a pre/post randomized trial over four weeks to explore the impact of olive oil on blood glucose and lipids levels among a randomly selected sample of 45 subjects with T2DM in Jordan. ${ }^{43}$ Study participants were asked to consume $30 \mathrm{~mL}$ of olive oil distributed after the three meals, breakfast, lunch and dinner. The study findings identified a significant improvement in fasting blood glucose and lipids levels due to the consumption of olive oil. ${ }^{43}$

Lunch is considered the main meal of the day and generally contains rice, bread and vegetables and sometimes meat. A cross-sectional study found cereals such as rice and wheat were the main components of the daily diets among patients with T2DM. ${ }^{34}$ High fruits and vegetables consumption were also found, and sodium intake was high in the form of added salt among patients with T2DM. Furthermore, sugar and carbohydrate intakes were high, and most of the consumed sugar was in the form of added sugar. ${ }^{34}$

People in Jordan insist on taking honey because of the cultural and religious values of this food. Honey is mentioned in the Holy Qur'an as blessed food and a source of 
healing. ${ }^{37}$ People believe drinking honey daily can protect them from illness and can be a cure for diseases. Honey is one of the main ingredients of Islamic medicine, and it is used as medicine to treat some patients. ${ }^{37}$ Honey has therapeutic properties that include antimicrobial effects and the ability to enhance wound healing. Therefore, honey is being used as topical treatment of diabetic foot ulcers among patients with diabetes and some of wound dressings contain modern medical grade honey. ${ }^{60}$ However, honey has a high glycemic index value which is absorbed rapidly increasing blood glucose levels. ${ }^{28}$

Evidence shows that the Jordanian diet has altered to be low in fruits, vegetables and high in fats and sugar and this alteration in Jordanian diet is likely associated with the rise in non-communicable conditions such as T2DM and cardiovascular diseases. ${ }^{8,12}$ Jordan has witnessed this nutritional transition in food choices from the Mediterranean diet to the fast food pattern during the past 40 years. ${ }^{8,39}$

Studies show sugar intake is also high among people living in Jordan. ${ }^{6,11,34}$ Total fat daily intake rose from 87 g per person in 2006/2007 to $100 \mathrm{~g}$ per person in $2010 .^{39}$ The daily intake of energy also increased from $3031 \mathrm{Kcal} /$ day per capita in $2006 / 2007$ to $3325 \mathrm{Kcal} /$ day per capita in 2010 in Jordan. ${ }^{39}$ These figures show there has been a significant alteration in the Jordanian diet to be low in fruits and vegetables and high in energy, fat, cholesterol, sugar and salt which are considered as the main characteristics of a Western diet. ${ }^{39}$ Furthermore, the increasing number of fast food restaurants across Jordan leads to an increase in the availability of fast foods. Fast food, cakes, cookies, pies and fried foods contain trans fats which can lead to high levels of blood cholesterol and contribute to weight gain. ${ }^{12,36}$ Weight gain and hyperlipidemia are considered the main risk factors for diabetes and diabetesrelated complications. ${ }^{1}$ A cross-sectional study showed that $90 \%$ of a sample of 702 patients with T2DM had one or more types of dyslipidemia in Jordan. The most common dyslipidemia was high LDL-cholesterol and high triglyceride. $^{45}$

\section{Physical activity}

The Eastern Mediterranean Region, including Jordan, had the highest prevalence of physical inactivity among the World regions in $2010 .^{2}$ The rapid changes in physical activity and food habits have led to the coexistence of many nutritional problems that underlie many chronic conditions such as T2DM in Jordan. ${ }^{8}$ A review of
Jordanian literature found that a rise in the prevalence of non-communicable conditions in Jordan is attributed to high levels of physical inactivity and a sedentary lifestyle. ${ }^{40}$ Sedentary behaviors refer to activities with a very low energy expenditure that are performed mainly in a sitting or supine position such as sleeping, sitting, lying down and watching television. ${ }^{59}$ The recommended physical activity guidelines for people with diabetes are 30 mins of moderate to vigorous intensity exercise per day on five days a week and muscle-strengthening exercises on two or more days a week. ${ }^{58}$ Moderate exercise means a person can be able to talk during activity and vigorous exercise implies a person cannot say more than a few words without pausing for a breath during the exercise. ${ }^{58}$

People in Jordan perceive physical activity and joining a gym as leisure and secondary activities. Physical exercise is not considered a priority within Jordanians' daily routine activities. ${ }^{4}$ According to the findings of a crosssectional survey of a randomly selected sample of 3196 men and women who were all aged $\geq 18$ years, $12.5 \%$ were physically active, and $55.9 \%$ of the participants recognized the recommended physical activity guidelines in Jordan. ${ }^{41}$

Despite the publication of research findings that have shown the importance of physical activity, the recommended physical activity among patients with diabetes in Jordan is still low. Low levels of physical activity are reported as being common among patients with poorly controlled diabetes. ${ }^{10,11,42}$ A cross-sectional study revealed that $51(45.1 \%)$ patients reported walking as the most common exercise and lack of desire, time, and having diabetes were reasons for not exercising. ${ }^{42}$

Social and cultural norms influence patients with diabetes to be able to do the recommended physical activity. Women face disapproval from society to join health clubs or to exercise in public places. ${ }^{41}$ Therefore, females with T2DM have to find other exercise options that they could engage in. Socio-cultural barriers restricted the women to engage in outdoor physical activities such as jogging and running. Low levels of physical activity among women were attributed to barriers such as social and cultural norms and caring for children or older people. ${ }^{41}$ Additionally, most of the sports facilities in Jordan are accessible to men only, and a few sports clubs allow limited times for women to exercise.

\section{Adherence to medications}

Adherence to the medication regimen is challenging for people with diabetes, especially for people who have more 
than one chronic condition such as diabetes and hypertension. Adherence is defined as the extent to which a person's behavior - taking medication, following a diet, and/or executing lifestyle changes, corresponds with agreed recommendations from a health care provider. $^{46}$ Taking multiple pharmacological treatments and regular dosages may negatively influence patient's adherence to T2DM medication regimen. ${ }^{47,48}$

Diabetic pharmacological treatments consist of oral hypoglycemic agents and insulin. ${ }^{28}$ Insulin is a hormone that is produced in the pancreas in response to high blood glucose levels. Insulin helps the body to use or to store the sugar that is gained from food. ${ }^{1}$ Most people with T2DM consider adding insulin therapy to their treatment regimen as an indicator of the unsatisfactory progress of the disease. ${ }^{36}$ The complexity of insulin therapy, the sign of poor progress and negative beliefs towards insulin are associated with psychological insulin resistance phenomenon. ${ }^{64}$ This phenomenon was also identified among people with poorly controlled T2DM in Jordan. A qualitative study with 38 patients with T2DM identified that fear of painful injections, an indicator of poor glycemic control and hypoglycemia were the main barriers regarding insulin therapy reported among the patients. ${ }^{56}$ A cross-sectional study also found that the high prevalence of poorly controlled T2DM among patients who were taking a combination therapy of oral hypoglycemic agents and insulin contributed to the delay in adding insulin to the medication regimen by doctors in Jordan. ${ }^{10}$ Therefore, these patients associated insulin therapy with a severe stage of diabetes and the development of complications. Patients' perceptions of insulin therapy are supported by another cross-sectional study which found that insulin therapy was perceived by patients as an indicator of poor glycemic control. ${ }^{11}$ This perception was attributed to more than half of the patients who were using insulin being more likely to have high $\mathrm{HbA1c}$ values ( $\geq 7 \%$ ), and insulin being added to their treatment therapy as a result of worsening glycemic control. ${ }^{11}$

Adherence to pharmacological treatment is influenced by several factors. The ability of people with T2DM to follow their medication regimen was compromised by multiple barriers such as long-term multi-therapies, adverse effects of medications and patients not understanding the information given by health care providers. ${ }^{47}$ A qualitative study with 36 Jordanians with T2DM showed that concerns about side effects of the medications, lack of confidence in the effectiveness of diabetes medications and fear from insulin injections affected participants' adherence to the medication regimen. ${ }^{48}$ A crosssectional survey conducted in Jordan revealed that $38.4 \%$ of the 902 people with chronic conditions including T2DM reported forgetfulness as the main barrier to adherence to the medication regimen and $13.1 \%$ stated that they did not like taking medications. ${ }^{50}$

In addition to forgetfulness and aversion, adverse effects of medications and multiple medications were other main barriers to adherence to the medication regimen in this study. Furthermore, another cross-sectional survey also reported that difficulties with having prescription refills on time, multiple medications, adverse effects of medications and negative beliefs were the main factors associated with a poor adherence rate. ${ }^{51}$

The literature suggests that Jordanian patients with diabetes believe that adherence to medications is sufficient to manage their condition and is more important than other diabetes management behaviors. ${ }^{10,11,19,31}$ A questionnaire was used to explore diabetes self-management behaviors among 917 patients with T2DM in the past 7 days. ${ }^{10}$ The study results illustrated that $91.9 \%$ of the participants were adherent to medication regimen compared with $38.1 \%$ who monitored blood glucose levels at home, $18.6 \%$ followed a diabetic diet and $32.1 \%$ of the participants engaged in physical activity. ${ }^{10}$

Other researchers have explored the reasons behind the high adherence rate of taking medications among all diabetes management behaviors in Jordan. ${ }^{11,19}$ A crosssectional study with 223 patients with T2DM found that high adherence to the medication regimen among patients was attributed to patients' perceptions toward diabetes management and potential barriers to adhering to other diabetes management behaviors such as social, cultural, financial and medical factors that were not measured in the study. ${ }^{11}$ Furthermore, a cross-sectional survey found that lifestyle modification was the main barrier to adhere to other T2DM management behaviors such as diet and exercise, foot care and blood glucose monitoring in Jordan. $^{19}$

\section{Monitoring blood glucose}

Blood glucose levels are assessed from blood obtained via finger prick tests using blood testing meters and test strips. Monitoring blood glucose is a skill that most people with diabetes should be able to accomplish. ${ }^{28}$ However, there is no evidence regarding the optimal frequency of selfmonitoring blood glucose (SMBG), and the level of 
adherence to prescribed SMBG varies from one individual to another and what type of treatment that the patient takes. ${ }^{49}$ For instance, patients with T2DM who are on diet or metformin alone with good controlled diabetes do not need to do SMBG on a daily basis. ${ }^{28}$

Glycemic control is essential to monitor diabetes management, and tight glycemic control has been shown to decrease the rates of diabetes-related complications. ${ }^{1}$ A cross-sectional study illustrated that $61.9 \%$ of the 917 patients with T2DM did not monitor their blood glucose at home and poorly controlled T2DM was also high among them. ${ }^{10}$ This result is similar to another study which showed that $24 \%$ of 649 participants measured their blood glucose at home for 5 days or more in the previous 7 days. ${ }^{31}$

Adherence to SMBG includes correct performance and frequency. Studies in Jordan ${ }^{10,19,31}$ focused only on frequency and did not assess the performance. These studies did not mention whether the participants received proper training about SMBG or not which is considered as a cornerstone before SMBG is practiced by people with diabetes. ${ }^{28}$ SMBG was found as the least performed behavior among the diabetes management behaviors and low motivation was the main barrier to SMBG regimen. ${ }^{19}$ Furthermore, the cost, being a waste of time, emotional anxiety, lack of knowledge about reading results and being painful were also reported as the main barriers to adhering to the SMBG regimen. ${ }^{52,56}$

A cross-sectional survey with 1079 patients with diabetes found patients who received health education about SMBG showed higher SMBG adherence in Jordan. ${ }^{53}$ This study also found that patients taking oral hypoglycemic tablets and/or insulin therapy were more likely to adhere to SMBG as compared to those on only diet or lifestyle modifications. ${ }^{53}$

\section{Foot care}

Diabetic foot problems such as amputation, infection and foot ulceration are considered as significant causes of disability and morbidity among patients with diabetes. ${ }^{49}$ However, diabetic foot problems can be prevented or delayed by annual comprehensive foot examination, foot care education and well-controlled diabetes. ${ }^{49}$ Proper footwear, foot hygiene and regular examination of feet for signs of neuropathy, impaired blood flow and skin changes can also prevent foot ulcers that often lead to gangrene and limb amputation. ${ }^{63}$

A longitudinal cohort study was identified which had followed up 60 patients with a diabetic foot infection between 2005 and 2007 to identify the progression of diabetic foot infection. ${ }^{54}$ Diabetic foot treatment protocol in the selected study setting consisted of three phases of interventions. The first phase of treatment began with debridement and when debridement failed, the amputation of one or more toes was considered. When infection remained uncontrolled, a below-knee amputation procedure was needed to eradicate the infection. The results showed that $17 \%(\mathrm{n}=10)$ of participants had below-knee amputation which was not linked to the duration of diabetes or type of treatment. It was associated with neuropathy in which $70 \%(\mathrm{n}=41)$ of the study participants had neuropathy. ${ }^{54}$

Diabetic neuropathy is considered the leading risk factor for the development of diabetic foot problems. ${ }^{63}$ A cross-sectional study was conducted to estimate the prevalence rate of diabetic neuropathy among 1003 patients with T2DM in Jordan. ${ }^{21}$ The overall prevalence of diabetic neuropathy was $39.5 \%$ out of the 1003 patients, and $57.9 \%$ of the patients $(\mathrm{n}=581)$ had an HbAlc more than $7 \% .^{21}$

Another cross-sectional survey with 1000 patients with diabetes illustrated that the prevalence of foot ulcers was $4.6 \%$, neuropathy $14.9 \%$, ischemia $7.5 \%$ and amputation $1.7 \%$ in Jordan. ${ }^{55}$ Poorly controlled diabetes and obesity were high at $77 \%$ and $50 \%$ among participants, respectively. ${ }^{55}$ However, the study findings were not linked to poor glycemic levels or obesity. The findings mainly were associated with duration of diabetes, neuropathy and male gender.

Two cross-sectional surveys found that feet washing was the most performed foot care behavior and inspecting the inside of shoes was the least performed among patients with T2DM in Jordan. ${ }^{11,19}$ The high adherence to feet washing was attributed to Muslim participants who have to wash their feet at least once a day as a religious practice before prayer. ${ }^{19}$

A qualitative study conducted with seven patients with diabetes found that health promotion and prevention regarding foot health are not addressed effectively in the health care system in Jordan which mainly focuses on management of acute diabetic foot problems. ${ }^{57}$ For instance, health care providers did not examine the feet of a person with diabetes on a regular basis in Jordan. ${ }^{19,57}$

There is a scarcity of data regarding the availability of necessary diabetic foot examination procedures such as foot vibration perception by tuning fork and foot vascular status by Doppler in the primary care settings in Jordan. ${ }^{2}$ If 
these basic procedures are not available in rural areas in Jordan, patients have to travel to hospitals to seek foot examination or not having their feet examined which may result in a delay in seeking foot care. ${ }^{57}$ Furthermore, participants did not practice preventive foot care behaviors as they believed that regular self-monitoring of the foot was not an element of diabetes management behaviors unless a foot ulcer was present. ${ }^{19,57}$ Foot care was not seen as a preventive measure but only something to be practiced once a problem had occurred.

\section{Attitudes, knowledge and perceptions of patients with diabetes regarding their condition}

Several studies have shown that diabetes knowledge is important to change management behaviors among patients in Jordan. ${ }^{8,11,35,48}$ However, knowledge alone is not enough to change behaviors, and it should be complemented by behaviors and positive attitudes toward diabetes and the treatment plan. ${ }^{61}$

A cross-sectional survey with 223 patients with T2DM found that poorly controlled T2DM was high among insulin users which might be attributed to limited knowledge, abilities or skills. ${ }^{11}$ A review of the literature also showed patients with diabetes often score poorly on diabetes knowledge tests in Jordan. ${ }^{35,62}$ In a cross-sectional study of 100 diabetic patients, the average score was 49.8 $\pm 13.4 \%$ using Fitzgerald's (1998) questionnaire to assess general diabetes knowledge and insulin knowledge. ${ }^{35}$

There are also other factors which may attribute to low levels of knowledge among patients with diabetes. Literature reported that low literacy rates, low family income and low self-care were the factors which contribute to poor knowledge levels among patients with diabetes in Jordan. ${ }^{35}$ Patients with diabetes sought their information about diabetes from family members or friends rather than health care professionals which may have contributed to poor knowledge levels among them. ${ }^{57}$

The family member with diabetes may be considered as a good source of information. Good support and a positive relationship with health care professionals also have been shown to have a positive impact on levels of knowledge among patients. ${ }^{17,35}$ A cross-sectional study with 237 patients with T2DM reported that $88.2 \%$ $(n=209)$ of the participants were aware that diabetes could affect the retina and $81.9 \%(n=194)$ patients mentioned that diabetic retinopathy could lead to blindness in
Jordan. ${ }^{17}$ Despite the high level of awareness about diabetic retinopathy in the study, the level of patients' compliance with behaviors to reduce the risk of retinopathy was low, with a total of $29.5 \%$ of the participants having had an eye examination in the previous year. ${ }^{17}$ This study's findings also reported that general practitioners, interpersonal relationships and the mass media were the main sources of information about diabetes among the study sample. ${ }^{17}$

Understanding patients' attitudes is essential to provide comprehensive diabetes care to patients. This may enable health care workers to identify patients' attitudes which may underpin their behaviors. From reviewing the literature, most of the studies about attitudes of people with diabetes in Jordan used the diabetes attitude questionnaires as the data collection tool ${ }^{10,52}$ which is identified as a shortfall in the literature. Patients with T2DM need to have the opportunity to express their feelings and concerns regarding their condition.

A qualitative study aimed to gain an in-depth understanding of attitudes, perceptions and knowledge among 38 patients with T2DM. ${ }^{56}$ Stress and family history were perceived as causes of developing diabetes and reasons for poorly controlled diabetes. Fatalistic beliefs were shared when the patients were talking about the causes of diabetes, the reasons for developing diabetes and their inability to control their blood glucose levels. ${ }^{56}$

\section{Complementary medicine and diabetes}

The complementary therapies are defined as a group of health care practices that are not part of that country's own conventional medicine and are not fully integrated into the dominant health care system. ${ }^{66}$ Examples of complementary therapies are herbs, herbal products that contain parts of plants, naturopathy, acupuncture, yoga and osteopathy. ${ }^{66}$

There are strong cultural and historical beliefs in complementary or alternative medicine (CAM) to be used in the management of chronic conditions including T2DM in Jordan. $^{70}$ Accessibility, affordability and availability of herbs in Jordan encourage patients with diabetes to incorporate herbs into their diabetes management plan. ${ }^{71}$ Moreover, herbalism is an indigenous symbol in Jordanian culture. ${ }^{70}$ For example, a cross-sectional study was conducted to explore dietary knowledge among 180 females with diabetes found that approximately half of them $(n=88)$ had a strong belief in the benefits of herbal and traditional medicine in the management of diabetes in Jordan. ${ }^{8}$ In addition to the abovementioned factors, there 
are several explanations for using herbal medicine in the management of diabetes in Jordan as presented in the following study. A cross-sectional survey illustrated that $16.6 \%(n=166)$ of a sample of 1000 patients with diabetes were users of herbal remedies in Jordan and green tea was the most popular herb used by participants. ${ }^{71}$ The main reasons for using herbs in this study were attributed to relieving diabetes symptoms, curing diabetes, slowing disease progression and reducing the undesirable side effects of medications.

People in Jordan are strongly influenced by instructions and recommendations mentioned by Prophet Muhammad (the Prophet of Islam) and in Islamic traditions. In addition to the cultural and heritage meaning of herbs, patients tend to use herbs due to religious beliefs. Ginger, olives, black cumin, fenugreek and garlic are examples of herbs mentioned in the Holy Quran and by Prophet Muhammad. ${ }^{72}$ Indigenous Arabic and Islamic Medicine incorporate healing practices such as medicinal plants that emerged from Islamic religion, the medicine of the Prophet (also known as Tibb Nabawi in Arabic) and cultural norms of the inhabitants. ${ }^{73}$ For instance, 26 plants have been used in the management of diabetes mentioned in Arab medicine. ${ }^{74}$ Examples of the used parts of plants are leaves, flowers, seeds and roots. ${ }^{72}$

Research about the beneficial features of plants has attracted many researchers worldwide. Experimental studies in vitro and animals have suggested multiple hypoglycemic effects of using herbal remedies among patients with diabetes. For example, Abelmoschus esculentus (okra), Allium cepa (onion), Allium sativum (garlic), Cinnamon zeylaniucm blume (cinnamon), Nigella sativa (black cumin), Olea europaea (olive leaves), Trigonella foenum-graecum (fenugreek) and Teucrium polium (germander) have beneficial properties such as improving insulin secretion, lowering fasting blood glucose, increasing glucose utilization by body tissues and delaying gastric emptying of carbohydrates after eating. ${ }^{69,72}$ These herbs, plants and spices are commonly used among patients with diabetes in Jordan (Table 1).

Health care workers are likely to underestimate the use of traditional medicine by showing negative attitudes toward it such as lack of trust and conviction towards using herbs as part of disease management. ${ }^{68}$ These negative attitudes of health care workers towards herbal use may hinder patients from discussing their herbal knowledge and usage with them. Health care providers are
Table I The English, local and scientific names of herbs that were used by patients with diabetes in Jordan. ${ }^{70,71}$

\begin{tabular}{|l|l|l|}
\hline English name & Local name & Scientific name \\
\hline Cinnamon & Kerfah & Cinnamon zeylaniucm blume \\
Fenugreek & Helba & Trigonella foenum-graecum \\
Garlic & Thoom & Allium sativum \\
Germander & Geádah & Teucrium polium \\
Ginger & Zanjabeel & Zingiber officinale Rosc. \\
Okra & Bamia & Abelmoschus esculentus \\
Olive leaves & Waraq Zaytoon & Olea europaea \\
White lupine & Termos & Lupinus albus L \\
\hline
\end{tabular}

encouraged to provide patients with appropriate health advice that is consistent with patients' beliefs and values. Health care providers may routinely explore patients' use of herbs and spices when taking patients' histories and prescribing their medications which could influence their glycemic control. ${ }^{56}$

A cross-sectional survey with 700 patients with chronic conditions including 260 patients with diabetes aimed to explore the prevalence of herbal medicine use in Jordan. ${ }^{70}$ $7.6 \%(n=53)$ of the 700 patients used herbs and $22.6 \%$ $(n=12)$ of the patients who used herbs informed their doctors about their use and the main sources of herbal information were family and friends. ${ }^{70}$ Health care providers could usefully increase patients' awareness of unsupervised herbal usage and encourage them to report using herbs. Herbal usage may lead to adverse effects among patients with chronic conditions including T2DM in Jordan due to co-morbidities and plant-drug interactions. ${ }^{70}$

Different names such as folk healers, herbalists and traditional healers are given to a person who is expert in preparing the appropriate recipes and mixtures of herbs for treating disease.$^{70}$ Most of the local healers in Jordan gained their experience from verbal instructions from their ancestors. ${ }^{67}$ Moreover, herbal knowledge is often inherited and transmitted across family members and generations without acquiring a formal education. ${ }^{71,74}$

Safety and efficiency of herbs are important topics that are discussed in a number of different studies recently. Safety, undesirable effects, regulations, standards and preparations of herbs are examples of the main challenges that concern health care professionals and policymakers worldwide. ${ }^{66}$ Two Jordanian studies reported adverse effects of using plants and herbs. For instance, comorbidities, interactions with other medications, contamination, purchasing herbs from open containers and 
inaccurate dosing are examples of risks associated with herbal usage in Jordan. ${ }^{70,71}$ As high as $13.2 \%$ of the 53 patients with chronic conditions including T2DM in Jordan used plants and herbs in pharmacological dosage form. ${ }^{70}$ A scarcity of supporting clinical data for herbs and plants in comparison to conventional drugs is also considered as the main challenge of using herbs. ${ }^{65}$ It is recognized that many conventional medicines are derived from plants.

\section{Discussion}

A comprehensive search of the literature yielded 32 studies conducted in Jordan between 2006 and 2019. Critiques and limitations of these studies have been discussed. This review identified that social, cultural and religious factors influence diabetes management, so there is a need for research approaches which enable these factors to be explored. Despite the importance of these factors in the Jordanian context, there is very little research conducted on the influence of these factors on the management of diabetes in Jordan. There is a shortfall in qualitative research and literature reviews in exploring the factors associated with the management of T2DM among patients.

This literature search and review identified that the crosssectional survey is the most popular research design in the published articles and papers related to diabetes (27 out of 32 ) in Jordan. This may raise concerns that cross-sectional studies represent a single point in time and may not be able to provide information about cause-and-effect relationships. Also, cross-sectional studies do not address the possibility of various changes over a period of time especially adherence to long-term diabetes management behaviors such as diet, exercise, SMBG, foot care and medications which is considered as a shortfall in the literature. In the qualitative studies $(n=2)$ in this review, the small sample size was reported as a limitation which limits the generalizability of the findings of these studies. Also, there is a shortfall in research in exploring patients' family members' perceptions of the factors that contribute to poor glycemic levels among patients with T2DM. Despite the important role of family members in patient's management of diabetes, none of the studies in this review included patients' family members.

The data regarding adherence to diabetes management behaviors in most of the studies $(n=19)$ were based on a selfreport which might be subject to recall and socially desirable answers biases. Also, another concern was the use of the same tool by asking participants to report the number of days of performing the diabetes management behaviors in the previous seven days. Therefore, the use of self-reported measures may be leading to recall bias and data on diabetes management behaviors were collected only once, and may not reflect long-term behaviors. In Jordan, although most of the patients with $\mathrm{T} 2 \mathrm{DM}$ receive their diabetes treatment through primary care services, only three studies in this review were conducted in primary care settings.

The sampling strategy in most of the studies (14 out of 32) was convenience followed by random selection (13 out of 32) by recruiting patients from one clinic and not from other health care settings which limits the generalizability of the findings. Approximately a third of the studies in Jordan (10 out of 32) were conducted in the National Diabetes Centre, and the study participants were more likely to have severe diabetes and complications. Therefore, there may be an overestimation of the prevalence of diabetes complications among the study patients which may not reflect all patients with T2DM in Jordan. The National Diabetes Centre is not accessible to all people especially those who live in rural areas, which may further limit the generalization of the study findings. Also, the high prevalence of poorly controlled diabetes might explain the high prevalence of diabetes-related complications amongst the samples in the studies in this review.

\section{Conclusion}

Many barriers exist to hinder adherence to diabetes management plan. The findings of this review indicate that patients' adherence is affected by multiple determinants. Patients' misconceptions about diabetes, beliefs about medications, lack of awareness and negative attitudes toward diabetes were among intrapersonal factors that hindered adherence to the management plan. Patients' relationships and interactions with immediate family and friends especially regarding family support, sources of information and home food environment were among interpersonal relationships. The traditional eating customs, food culture, herbal usage and lack of culturally sensitive health clubs were among the socio-cultural factors that influenced patients' diabetes management behaviors at the larger social system. Health care providers need to address the issue of poor glycemc control among patients and the barriers that influence adherence to the diabetes management plan.

\section{Abbreviation list}

BMI, Body Mass Index; CAM, Complementary or Alternative Medicine; CASP, Critical Appraisal Skills 
Program; PRISMA, Preferred Reporting Items for Systematic Reviews and Meta-Analyses; SMBG, Selfmonitoring blood glucose; T2DM, Type-2 Diabetes Mellitus; UAE, United Arab Emiratis.

\section{Disclosure}

The authors report no conflicts of interest in this work.

\section{References}

1. IDF. IDF Diabetes Atlas. 8th; 2017. Available from: http://www. diabetesatlas.org. Accessed August 4, 2018.

2. World Health Organisation. Jordan: diabetes country profiles; 2016b. Available from: https://www.who.int/diabetes/country-profiles/jor_en. pdf. Accessed June 7, 2018

3. Boutayeb A, Lamlili M, Boutayeb W, Maamri A, Ziyyat A, Ramdani N. The rise of diabetes prevalence in the Arab region. Open J Epidemiol. 2012;02(02):55-60. doi:10.4236/ojepi.2012.22009

4. Zindah M, Belbeisi A, Walke H, Mokdad A. Obesity and diabetes in Jordan: findings from the behavioural risk factors surveillance system, 2004. Prev Chronic Dis. 2008;5(1-8).

5. Al-Shudifat A, Johannessen A, Azab M, Abumweis S, Agraib L, Tayyem R. Risk factors for coronary artery disease in patients undergoing elective coronary angiography in Jordan. BMC Cardiovasc Disord. 2017;17(1). doi:10.1186/s12872-017-0620-4

6. Sharara E, Akik C, Ghattas H, Obermeyer C. Physical inactivity, gender and culture in Arab countries: a systematic assessment of the literature. BMC Public Health. 2018;18(1):1-19. doi:10.1186/ s12889-018-5472-z

7. World Health Organisation. Obesity; 2018. Available from: https:// www.who.int/topics/obesity/en. Accessed March 4, 2019.

8. El-Qudah J. Dietary knowledge among female diabetic patients in Amman, Jordan. Curr Res Nutr Food Sci J. 2016;4(2):107-113. doi:10.12944/CRNFSJ.4.2.04

9. Alsairafi Z, Taylor K, Smith F, Alattar A. Patients' management of type 2 diabetes in Middle Eastern countries: review of studies. Patient Prefer Adherence. 2016;1051. doi:10.2147/ppa.s104335

10. Khattab M, Khader Y, Al-Khawaldeh A, Ajlouni K. Factors associated with poor glycaemic control among patients with Type 2 diabetes. J Diabetes Complications. 2010;24(2):84-89. doi:10.1016/ j.jdiacomp.2008.12.008

11. Al-Khawaldeh O, Al-Hassan M, Froelicher E. Self-efficacy, self-management, and glycaemic control in adults with type 2 diabetes mellitus. $J$ Diabetes Complications. 2012;26(1):10-16. doi:10.1016/j.jdiacomp.2011.11.002

12. Al-Nsour M, Zindah M, Belbeisi A, Hadaddin R, Brown D, Walke H. Prevalence of selected chronic, no communicable disease risk factors in Jordan: results of the 2007 Jordan behavioural risk factor surveillance survey. Prev Chronic Dis. 2012. doi:10.5888/pcd9.110077

13. Critical Appraisal Skills Programme. CASP appraisal checklists; 2018. Available from: https://casp-uk.net/casp-tools-checklists. Accessed January 25, 2018

14. Khatib F, Jarrah N, Shegem N, Bateiha A, Abu-Ali R, Ajlouni K. Sexual dysfunction among Jordanian men with diabetes. Saudi Med J. 2006;27(3):351-356.

15. Al-Bdour M, Al-Till M, Samra K. Risk factors for diabetic retinopathy among Jordanian diabetics. Middle East Afr J Ophthalmol. 2008;15(2):77. doi:10.4103/0974-9233.51997

16. Rabiu M, Al Bdour M, Abu Ameerh M, Jadoon M. Prevalence of blindness and diabetic retinopathy in northern Jordan. Eur J Ophthalmol. 2015;25(4):320-327. doi:10.5301/ejo.5000557
17. Bakkar M, Haddad M, Gammoh Y. Awareness of diabetic retinopathy among patients with type 2 diabetes mellitus in Jordan. Diabetes Metab Syndr Obes. 2017;10:435-441. doi:10.2147/DMSO.S140841

18. Ajlouni K, Khader YS, Batieha A, Ajlouni H, El-Khateeb M. An increase in prevalence of diabetes mellitus in Jordan over 10 years. $J$ Diabetes Complications. 2008;22(5):317-324. doi:10.1016/j. jdiacomp.2007.01.004

19. Albikawi Z, Abuadas M. Diabetes self-care management behaviours among Jordanian type two diabetes patients. Am Int J Contemp Res. 2015;5(3):87-95.

20. Obeidat A, Ahmad M, Haddad F, Azzeh F. Alarming high prevalence of metabolic syndrome among Jordanian adults. Pak J Med Sci. 2015;31(6). doi:10.12669/pjms.316.7714

21. Khawaja N, Abu-Shennar J, Saleh M, Dahbour S, Khader Y, Ajlouni K. The prevalence and risk factors of peripheral neuropathy among patients with type 2 diabetes mellitus; the case of Jordan. Diabetol Metab Syndr. 2018;10(1):1-10. doi:10.1186/s13098-0180309-6

22. Nazer L, Tuffaha H. Health care and pharmacy practice in Jordan. Can J Hosp Pharm. 2017;70(2):150-155. doi:10.4212/cjhp. v70i2.1649

23. Musaiger A, Al-Mannai M, Tayyem R, et al. Prevalence of overweight and obesity among adolescents in seven Arab Countries: a cross-cultural study. J Obes. 2012;(2012:1-5. doi:10.1155/2012/ 981390

24. Ajlouni K, Jaddou H, Batieha A. Diabetes and impaired glucose tolerance in Jordan: prevalence and associated risk factors. $J$ Intern Med. 1998;244(4):317-323. doi:10.1046/j.1365-2796.1998.00369

25. Ali R, Al Hajeri R, Khader Y, Shegem N, Ajlouni K. Sexual dysfunction in Jordanian diabetic women. Diabetes Care. 2008;31:1580-1581.doi: 10.2337/dc08-0081.

26. Yasein N, Masa'D D. Metabolic syndrome in family practice in Jordan: a study of high-risk groups. East Mediterr Health J. 2011;17(12):943-948.

27. Khader Y, Khatatbeh M, El-Salem K, Amarin Z, Bateiha A. The metabolic syndrome -among patients undergoing cardiac catheterization in Jordan. $J$ Cardiometab Syndr. 2008;3(4):224-228. doi:10.1111/j.1559-4572.2008.00020

28. Hillson R. Diabetes Care: A Practical Manual. 2nd ed. Oxford: Oxford University Press; 2015.

29. Al-Amer R, Khader Y, Malas S, Abu-Yaghi N, Al-Bdour M, Ajlouni K. Prevalence and risk factors of diabetic retinopathy among Jordanian patients with type 2 diabetes. Digit J Ophthalmol. 2008;14:42. doi:10.5693/djo.01.2008.013

30. Irshaid F. Prevalence of insulin- treated Type-2 diabetes mellitus in northern Jordan: lifestyle, familial inheritance and maternal influence. Eur Sci J. 2014;10(12). doi:10.19044/esj.2014.v10n12p\%25p

31. Al-Amer R, Sobeh M, Zayed A, Al-Domi H. Depression among adults with diabetes in Jordan: risk factors and relationship to blood sugar control. J Diabetes Complications. 2011;25(4):247-252. doi:10.1016/j.jdiacomp.2011.03.001

32. Alhabashneh R, Khader Y, Herra Z, Asa'Ad F. The association between periodontal disease and metabolic syndrome among outpatients with diabetes in Jordan. J Diabetes Metab Disord. 2015;14 (1). doi:10.1186/s40200-015-0207-5

33. Al Omari M, Khader Y, Dauod A, et al. Glycaemic control among patients with type 2 diabetes mellitus treated in primary care setting in Jordan. Prim Care Diabetes. 2009;3(3):173-179. doi:10.1016/j. pcd.2009.08.004

34. Bawadi H, Abu-Jamous D, Tayyem R. Evaluation of the dietary pattern of patients with type 2 diabetes in Northern Jordan: an inconvenient truth. Int J Diabetes Dev Ctries. 2014;34(3):134-138. doi:10.1007/s13410-013-0149-8

35. Al-Sarihin K, Bani-Khaled M, Haddad F, Althwabia I. Diabetes knowledge among patients with diabetes mellitus at King Hussein hospital. Jrms. 2012;19(1):72-77. 
36. Unger J. Diabetes Management in Primary Care. 2nd ed. Philadelphia: Lippincott Williams and Wilkins; 2012.

37. Purbafrani A, Hashemi G, Amirhosein S, Bayyenat S, Taghizade Moghaddam H, Saeidi M. The benefits of honey in Holy Quran. Int $J$ Pediatr. 2014;2(3.3):67-73.

38. IDF. The IDF Consensus Worldwide Definition of the Metabolic Syndrome. Belgium: International Diabetes Federation; 2006.

39. Takruri H, Alkurd R. Intakes of fats, cholesterol, fiber and micronutrients as risk factors for cardiovascular disease in Jordan. Jordan J Biol Sci. 2014;7(2):119-126. doi:10.12816/0008225

40. Gallagher H, Gebhard M, Nash W, Occhipinti N, Walke B. The Jordanian Diabetes Crisis. Michigan: University of Michigan; 2008.

41. Barghouti F, Abu-Rmaileh N, Jallad D, Abd-Qudah Y. Leisure time physical activity in Jordan: knowledge and sociodemographic determinants. Int Med J. 2015;22(4):283-287.

42. Darawad M, Mosleh S, Khalil A, Maharmeh M, Hamdan-Mansour A, Samarkandi O. Investigating physical exercise among Jordanians with diabetes mellitus. Health. 2016;08(02):181-189. doi:10.4236/ health.2016.82021

43. Al Jamal A, Ibrahim A. Effects of olive oil on lipid profiles and blood glucose in type2 diabetic patients. Int $J$ Diabetes Metab. 2011;19:19-22.

44. Jammal H, Khader Y, Alkhatib S, Abujbara M, Alomari M, Ajlouni K. Diabetic retinopathy in patients with newly diagnosed type 2 diabetes mellitus in Jordan: prevalence and associated factors. J Diabetes. 2013;5 (2):172-179. doi:10.1111/1753-0407.12015

45. Abdel-Aal N, Ahmad A, Froelicher E, Batieha M, Hamza M, Ajlouni K. Prevalence of dyslipidemia in patients with type 2 diabetes in Jordan. Saudi Med J. 2008;29(10):1423-1428.

46. World Health Organization; SabatâE E. Adherence to Long-Term Therapies: Evidence for Action. Geneva: World Health Organization; 2003.

47. Antoine S, Pieper D, Mathes T, Eikermann M. Improving the adherence of type 2 diabetes mellitus patients with pharmacy care: A systematic review of randomized controlled trials. BMC Endocr Disord. 2014;14(1). doi:10.1186/1472-6823-14-53

48. Jarab A, Mukattash T, Al-Azayzih A, Khdour M. A focus group study of patient's perspective and experiences of type 2 diabetes and its management in Jordan. Saudi Pharm J. 2018;26(3):301-305. doi:10.1016/j.jsps.2018.01.013

49. American Diabetes Association. Standards of medical care in diabetes. Diabetes Care. 2013;36(Suppl 1):S11-S66. doi:10.2337/dc13-S011.

50. Awwad O, Akour A, Al-Muhaissen S, Morisky D. The influence of patients' knowledge on adherence to their chronic medications: a cross-sectional study in Jordan. Int J Clin Pharm. 2015;37 (3):504-510. doi:10.1007/s11096-015-0086-3

51. Basheti I, Hait S, Qunaibi E, Aburuz S, Bulatova N. Associations between patient factors and medication adherence: a Jordanian experience. Pharm Pract. 2016;14(1):639. doi:10.18549/ pharmpract.2016.01.639

52. Al-Maskari F, El-Sadig M, Al-Kaabi J, Afandi B, Nagelkerke N, Yeatts K. Knowledge, attitude and practices of diabetic patients in the United Arab Emirates. PLoS One. 2013;8(1):e52857. doi:10.1371/journal.pone.0052857

53. Al-Keilani M, Almomani B, Al-Sawalha N, Shhabat B. Selfmonitoring of blood glucose among patients with diabetes in Jordan: perception, adherence, and influential factors. Diabetes Res Clin Pract. 2017;126:79-85. doi:10.1016/j.diabres.2017.01.005

54. Salayta W, Aleyadeh A. The outcome of diabetic foot infection in Jordanian cohort. Rawal Med J. 2010;35(2):214-216.

55. Bakri F, Allan A, Khader Y, Younes N, Ajlouni K. Prevalence of diabetic foot ulcer and its associated risk factors among diabetic patients in Jordan. Jordan Med J. 2012;46(2):118-125.
56. Al-Sahouri A, Merrell J, Snelgrove S. Attitudes, knowledge, and perceptions of patients regarding type-2 diabetes in Jordan. J Diabetes Mellit. 2019;9:1-13. doi:10.4236/jdm.2019.91001

57. Abu-Qamar M, Wilson A. Foot care within the Jordanian healthcare system: a qualitative inquiry of patient's perspectives. Aust $J$ Adv Nurs. 2011;29(1):28-36.

58. American Diabetes Association. What we recommend; types of activity; 2015c. Available from: http:/www.diabetes.org/food-andfitness/fitness/types-of-activity/what-we-recommend.html. Accessed May 19, 2015

59. Tremblay MS, Aubert S, Barnes JD, et al. Sedentary behavior research network (SBRN)-terminology consensus project process and outcome. Int $J$ Behav Nutr Phys Act. 2017;14(1):75. doi:10.1186/s12966-017-0525-8

60. Cooper R. The use of honey in diabetic foot ulcers. Diabet Foot J. 2017;20(3):154-159.

61. Naidoo J, Wills J. Foundations of Health Promotion. 3rd ed. Edinburgh: Elsevier; 2009.

62. Habashneh R, Khader Y, Hammad M, Almuradi M. Knowledge and awareness about diabetes and periodontal health among Jordanians. $J$ Diabetes Complications. 2010;24(6):409-414. doi:10.1016/j. jdiacomp.2009.06.001

63. World Health Organization. Global Report on Diabetes. Geneva: World Health Organization; 2016a.

64. Holmes-Truscott E, Blackberry I, O’Neal D, Furler J, Speight J. Willingness to initiate insulin among adults with type 2 diabetes in Australian primary care: results from the stepping up study. Diabetes Res Clin Pract. 2016;114:126-135. doi:10.1016/j. diabres.2015.12.011

65. Bone A. Optimising safety. Principles Pract Phytother. 2013;100-117. doi:10.1016/B978-0-443-06992-5.00005-0

66. World Health Organisation. Who traditional medicine strategy; 2014. Available from: http://apps.who.int/iris/bitstream/handle/10665/ 92455/9789241506090_eng.pdf. Accessed May 1, 2016.

67. Payyappallimana U. Role of traditional medicine in primary health care: an overview of perspectives and challenging. Yokohama J Social Sci. 2010;14(6):721-743.

68. Helman C. Culture, Health and Illness: An Introduction for Health Professionals. 5th ed. Oxford: Elsevier Science; 2007.

69. Singab A, Youssef F. Medicinal plants with potential antidiabetic activity and their assessment. Med Aromat Plants. 2014;03(01). doi:10.4172/2167-0412.1000151

70. Wazaify M, Alawwa I, Yasein N, Al-Saleh A, Afifi F. Complementary and alternative medicine (CAM) use among Jordanian patients with chronic diseases. Complement Ther Clin Pract. 2013;19(3):153-157. doi:10.1016/j.ctcp.2013.03.001

71. Wazaify M, Afifi F, El-Khateeb M, Ajlouni K. Complementary and alternative medicine use among Jordanian patients with diabetes. Complement Ther Clin Pract. 2011;17(2):71-75. doi:10.1016/j. ctcp.2011.02.002

72. Ahmed H. Ethnopharmacobotanical study on the medicinal plants used by herbalists in Sulaymaniyah Province, Kurdistan, Iraq. $J$ Ethnobiol Ethnomed. 2016;12(1). doi:10.1186/s13002-0160081-3

73. Alrawi S, Fetters M. Traditional Arabic \& Islamic medicine: a conceptual model for clinicians and researchers. Glob J Health Sci. 2012;4(3). doi:10.5539/gjhs.v4n3p164

74. Saad B, Azaizeh H, Said O. Tradition and perspectives of arab herbal medicine: a review. Evid Based Complementary Altern Med. 2005;2 (4):475-479. doi:10.1093/ecam/neh133 


\section{Supplementary materials}

Table S1 Summary of the studies that were reviewed in this literature

\begin{tabular}{|c|c|c|c|}
\hline $\begin{array}{l}\text { Author/s and } \\
\text { date }\end{array}$ & $\begin{array}{l}\text { Sample size and } \\
\text { characteristics }\end{array}$ & $\begin{array}{l}\text { Research design and methods of } \\
\text { data collection }\end{array}$ & Main findings \\
\hline $\begin{array}{l}\text { El-Qudah, } 2016^{8} \\
\text { Different hospitals in } \\
\text { Amman, Jordan. }\end{array}$ & $\begin{array}{l}\text { Convenience sampling, } \\
\text { I } 80 \text { females with diabetes }\end{array}$ & $\begin{array}{l}\text { Cross-sectional study. Dietary knowledge } \\
\text { was assessed by a self-reported } \\
\text { questionnaire. }\end{array}$ & $\begin{array}{l}\text { More than half of patients }(56.1 \%) \text { provided } \\
\text { wrong answers for meals recommended for } \\
\text { diabetes/day and that should be used with } \\
\text { hypoglycemia, food rich in protein, number } \\
\text { of snacks }(50.6 \%) \text { and their role ( } 43.1 \%) \text {, } \\
\text { drinks permitted with unlimited amounts } \\
(61.4 \%) \text { and suitable time to drink juice } \\
(78.1 \%) \text {. }\end{array}$ \\
\hline $\begin{array}{l}\text { Khattab et al, } 2010 . .^{10} \\
\text { The National Diabetes } \\
\text { Centre, Jordan. }\end{array}$ & $\begin{array}{l}\text { Systematic random sam- } \\
\text { ple, } 917 \text { patients with } \\
\text { T2DM. }\end{array}$ & $\begin{array}{l}\text { Cross-sectional study. Sociodemographic } \\
\text { data and diabetes self-management beha- } \\
\text { viours were collected by questionnaire. } \\
\text { All blood glucose levels and lipid profiles } \\
\text { were taken from patients' files. }\end{array}$ & $\begin{array}{l}65.1 \% \text { had } \mathrm{HbAlc} \geq 7 \% \text { and negative attitude } \\
\text { towards diabetes. }\end{array}$ \\
\hline $\begin{array}{l}\text { Al-Khawaldeh et al, } \\
\text { 20I2." The National } \\
\text { Diabetes Centre, } \\
\text { Jordan. }\end{array}$ & $\begin{array}{l}\text { Convenience sample, } 223 \\
\text { patients with T2DM. }\end{array}$ & $\begin{array}{l}\text { Cross-sectional survey. Data were collected } \\
\text { by diabetes management self-efficacy scale, } \\
\text { and a diabetes self-management behaviours } \\
\text { scale }\end{array}$ & $\begin{array}{l}\text { Diet self-efficacy and diet self-management } \\
\text { behaviours predicted better glycemic con- } \\
\text { trol, whereas insulin use was a predictor for } \\
\text { poor glycemic control. }\end{array}$ \\
\hline $\begin{array}{l}\text { Khatib et al, } 2006 .^{14} \\
\text { The National Diabetes } \\
\text { Centre, Jordan. }\end{array}$ & $\begin{array}{l}\text { Convenience sampling, } \\
988 \text { patients with } \\
\text { diabetes. }\end{array}$ & $\begin{array}{l}\text { Cross-sectional survey. The prevalence rate } \\
\text { of erectile dysfunction was measured by } \\
\text { structured interviews. }\end{array}$ & $\begin{array}{l}\text { The overall prevalence of erectile dysfunc- } \\
\text { tion was } 62 \% \text { and } 30.3 \% \text { had severe erectile } \\
\text { dysfunction. }\end{array}$ \\
\hline $\begin{array}{l}\text { Al-Bdour et al, } 2008 .^{15} \\
\text { Jordan University } \\
\text { Hospital. }\end{array}$ & $\begin{array}{l}\text { Convenience sampling, } \\
\text { I96I patients with } \\
\text { diabetes. }\end{array}$ & $\begin{array}{l}\text { Cross-sectional survey. Full eye examina- } \\
\text { tion, biochemical measurements and medi- } \\
\text { cal assessment were used to collect data } \\
\text { about risk factors for diabetic retinopathy. }\end{array}$ & $\begin{array}{l}64.1 \%(n=1257) \text { were found to have one } \\
\text { type of diabetic retinopathy, and there was } \\
\text { association between diabetic retinopathy } \\
\text { with poorly controlled diabetes and longer } \\
\text { duration of disease. }\end{array}$ \\
\hline $\begin{array}{l}\text { Rabiu et al, } 2015 .^{16} \\
\text { North Jordan, Jordan. }\end{array}$ & $\begin{array}{l}\text { Random selection, } 104 \\
\text { patients with diabetes. }\end{array}$ & $\begin{array}{l}\text { Cross-sectional study. } \\
\text { Data were collected by standardized exam- } \\
\text { ination protocol, which included ophthalmic } \\
\text { examination, random blood sugar test using } \\
\text { digital glucometers and dilated fundus } \\
\text { examination. }\end{array}$ & $\begin{array}{l}\text { Untreated cataract and diabetic retinopathy } \\
\text { were the major causes of blindness, } \\
\text { accounting for } 46.7 \% \text { and } 33.2 \% \text { of total } \\
\text { blindness cases, respectively. The prevalence } \\
\text { of any retinopathy was } 48.4 \% \text {. }\end{array}$ \\
\hline $\begin{array}{l}\text { Bakkar et al, } 2017 .{ }^{17} \\
\text { General population; } \\
\text { Amman, Zarqa, and } \\
\text { Irbid. }\end{array}$ & $\begin{array}{l}\text { Random selection, } 237 \\
\text { patients with T2DM. }\end{array}$ & $\begin{array}{l}\text { Cross-sectional study. Awareness and } \\
\text { knowledge of diabetes and diabetic } \\
\text { Retinopathy were assessed by } \\
\text { a questionnaire. }\end{array}$ & $\begin{array}{l}88.2 \% \text { were aware that diabetes can affect } \\
\text { the eyes and } 81 \% \text { reported that diabetic } \\
\text { retinopathy can lead to blindness. }\end{array}$ \\
\hline $\begin{array}{l}\text { Ajlouni et al, } 2008 .^{18} \\
\text { Comprehensive health } \\
\text { centre, Jordan. }\end{array}$ & $\begin{array}{l}\text { Random selection, II2I } \\
\text { participants (general } \\
\text { population). }\end{array}$ & $\begin{array}{l}\text { Cross-sectional survey. Data were collected } \\
\text { by sociodemographic questionnaire, } \\
\text { anthropometric and biochemical } \\
\text { measurements. }\end{array}$ & $\begin{array}{l}\text { The study findings identified } 195 \text { partici- } \\
\text { pants who had T2DM, of whom } 79 \text { (54\%) } \\
\text { were poorly controlled cases. }\end{array}$ \\
\hline $\begin{array}{l}\text { Albikawi and Abuadas, } \\
2015 .^{19} \text { Diabetes } \\
\text { Specialized } \\
\text { Centre, Jordan. }\end{array}$ & $\begin{array}{l}\text { Convenience sampling, } \\
49 \text { patients with T2DM. }\end{array}$ & $\begin{array}{l}\text { Cross-sectional study. Data about diabetes } \\
\text { management behaviours were collected by } \\
\text { a self-report questionnaire. }\end{array}$ & $\begin{array}{l}\text { The most frequently performed self-care } \\
\text { management behaviours was medication } \\
\text { taking followed by foot care, dietary adher- } \\
\text { ence, exercise, and the least performed } \\
\text { behaviour was blood glucose testing. }\end{array}$ \\
\hline
\end{tabular}

(Continued) 
(Continued).

\begin{tabular}{|c|c|c|c|}
\hline $\begin{array}{l}\text { Author/s and } \\
\text { date }\end{array}$ & $\begin{array}{l}\text { Sample size and } \\
\text { characteristics }\end{array}$ & $\begin{array}{l}\text { Research design and methods of } \\
\text { data collection }\end{array}$ & Main findings \\
\hline $\begin{array}{l}\text { Khawaja et al, } 2018 .^{21} \\
\text { The National Diabetes } \\
\text { Centre, Jordan. }\end{array}$ & $\begin{array}{l}\text { Convenience, } 1003 \\
\text { patients with T2DM. }\end{array}$ & $\begin{array}{l}\text { Cross-sectional study. } \\
\text { Data were collected from participants dur- } \\
\text { ing a face-to-face structured interview. }\end{array}$ & $\begin{array}{l}\text { The overall prevalence of diabetic neuropa- } \\
\text { thy was } 39.5 \% \text {, The most frequently } \\
\text { reported symptoms were numbness ( } 32.3 \%) \\
\text { and pain with walking ( } 29.7 \%) \text {, while the } \\
\text { least reported symptoms were the history } \\
\text { of amputation } \\
\text { (l.3\%), loss of sensation in legs/feet while } \\
\text { walking ( } 3.8 \%) \text {, and } 57.9 \% \text { of the patients } \\
(n=58 I) \text { had an HbAlc more than } 7 \% \text {. }\end{array}$ \\
\hline $\begin{array}{l}\text { Ali et al, } 2008 .^{25} \text { The } \\
\text { National Diabetes } \\
\text { Centre, Jordan. }\end{array}$ & $\begin{array}{l}\text { Random selection, } 613 \\
\text { female patients with dia- } \\
\text { betes and } 524 \text { women } \\
\text { without diabetes }\end{array}$ & $\begin{array}{l}\text { Cross-sectional study. sexual dysfunction } \\
\text { was measured by The Female Sexual } \\
\text { Function Index questionnaire }\end{array}$ & $\begin{array}{l}\text { Prevalence of sexual dysfunction in diabetic } \\
\text { women was } 59.6 \% \text { vs } 45.6 \% \text { in nondiabetic } \\
\text { women. }\end{array}$ \\
\hline $\begin{array}{l}\text { Yasein and Masa'd, } \\
201 \mathrm{I}^{26} \text { Jordan } \\
\text { University hospital, } \\
\text { Jordan. }\end{array}$ & $\begin{array}{l}\text { Random selection, } 730 \\
\text { Patients with chronic } \\
\text { conditions including } \\
\text { T2DM. }\end{array}$ & $\begin{array}{l}\text { Cross-sectional study. Data were collected } \\
\text { by sociodemographic questionnaire, } \\
\text { anthropometric (weight, height, hip, BP and } \\
\text { waist circumferences) and biochemical } \\
\text { (fasting blood glucose and lipid profile) } \\
\text { measurements. }\end{array}$ & $\begin{array}{l}\text { The prevalence of metabolic syndrome } \\
\text { was } 37.4 \% \text { ( } 31.7 \% \text { in men; } 41.0 \% \text { in } \\
\text { women). The prevalence increased with } \\
\text { age in the total sample and in both sexes. } \\
\text { High waist circumference showed the } \\
\text { highest prevalence in the total sample } \\
(61.6 \%) \text {. Among females it ranked as the } \\
\text { first criterion ( } 73.5 \%) \text {. High serum trigly- } \\
\text { ceride level showed the highest prevalence } \\
\text { in males }(50.2 \%) \text {. }\end{array}$ \\
\hline $\begin{array}{l}\text { Al-Amer et al, } 2008{ }^{29} \\
\text { The national diabetes } \\
\text { centre, Jordan. }\end{array}$ & $\begin{array}{l}\text { Random selection, } 1000 \\
\text { patients with T2DM }\end{array}$ & $\begin{array}{l}\text { Cross-sectional study. Prevalence and risk } \\
\text { factors of diabetic retinopathy were } \\
\text { assessed by eye examination. }\end{array}$ & $\begin{array}{l}\text { The prevalence of diabetic retinopathy in } \\
\text { patients was } \\
34.1 \% \text {. Duration of DM and hyperglycemia } \\
\text { were associated with diabetic retinopathy. }\end{array}$ \\
\hline $\begin{array}{l}\text { Al-Amer et al, 20I I. } \\
\text { Jordan University } \\
\text { Hospital, Jordan. }\end{array}$ & $\begin{array}{l}\text { Systematic random sam- } \\
\text { pling, } 649 \text { patients with } \\
\text { diabetes. }\end{array}$ & $\begin{array}{l}\text { Cross sectional study. Prevalence of undiag- } \\
\text { nosed depression and the relationship } \\
\text { between depression and blood sugar con- } \\
\text { trol were collected by a structured } \\
\text { questionnaire. }\end{array}$ & $\begin{array}{l}\text { I } 28 \text { (19.7) have depression, females are } \\
\text { more likely to develop depression than } \\
\text { males. } 64.7 \% \text { of participants did not follow } \\
\text { the diabetic diet and } 70.9 \% \text { of the partici- } \\
\text { pants were poorly controlled }\end{array}$ \\
\hline $\begin{array}{l}\text { Al Omari et al, } 2009 .{ }^{33} \\
\text { A primary care centre, } \\
\text { Jordan. }\end{array}$ & $\begin{array}{l}\text { Convenience sampling, } \\
337 \text { patients with T2DM. }\end{array}$ & $\begin{array}{l}\text { Cross sectional study. The data were col- } \\
\text { lected by reviewing the patients' medical } \\
\text { records }\end{array}$ & $\begin{array}{l}56.1 \% \text { had } \mathrm{HbAlc}<7 \% \text {. The mean } \mathrm{HbAlc} \\
\text { was } 7.1 \% \text {. Half of the patients achieved the } \\
\text { target levels of total cholesterol, triglycer- } \\
\text { ides and HDL. }\end{array}$ \\
\hline $\begin{array}{l}\text { Bawadi et al., } 2013 .^{34} \\
\text { King Abdulla } \\
\text { University Hospital, } \\
\text { Jordan. }\end{array}$ & $\begin{array}{l}\text { Convenience sampling, } \\
750 \text { patients with T2DM }\end{array}$ & $\begin{array}{l}\text { Cross-sectional survey. Dietary profile of } \\
\text { participants was assessed by a semi- } \\
\text { quantitative food frequency questionnaire } \\
\text { (FFQ). }\end{array}$ & $\begin{array}{l}\text { Patients reported high intakes of fruits and } \\
\text { grains, enough intakes of vegetables and } \\
\text { low intakes of milk, meat and beans. Daily } \\
\text { caloric consumption was } 65 \% \text { from car- } \\
\text { bohydrates, I } 3 \% \text { protein, and } 29 \% \text { fat } \\
\text { (distributed as } 8 \% \text { from saturated fat, } 14 \% \\
\text { from monounsaturated fat, and } 3.5 \% \text { from } \\
\text { polyunsaturated fat). }\end{array}$ \\
\hline
\end{tabular}

(Continued) 
(Continued).

\begin{tabular}{|c|c|c|c|}
\hline $\begin{array}{l}\text { Author/s and } \\
\text { date }\end{array}$ & $\begin{array}{l}\text { Sample size and } \\
\text { characteristics }\end{array}$ & $\begin{array}{l}\text { Research design and methods of } \\
\text { data collection }\end{array}$ & Main findings \\
\hline $\begin{array}{l}\text { Al-Sarihin et al, } 2012^{35} \\
\text { Hospital, Jordan. }\end{array}$ & $\begin{array}{l}\text { Convenience sample, } 100 \\
\text { patients with diabetes. }\end{array}$ & $\begin{array}{l}\text { Cross-sectional study. Data were collected } \\
\text { by using Fitzgerald's (1998) questionnaire to } \\
\text { assess general diabetes knowledge and } \\
\text { insulin knowledge. }\end{array}$ & $\begin{array}{l}\text { The overall scores of the total sample } \\
\text { were low; Total knowledge was ( } 49.8 \\
\pm \mid 3.4 \text { ); General Diabetes Knowledge was } \\
(54 \pm \mid 4) \text { and Insulin Knowledge was ( } 43 \\
\pm 19.6 \text { ). Men scored higher than women in } \\
\text { the total Knowledge ( } 52.9 \text { vs } 46.7) \text {; } \\
\text { General Diabetes Knowledge ( } 56.8 \text { vs } \\
5 I .1) \text {; and Insulin Knowledge ( } 46.9 \text { vs } \\
39.8) \text {. Moreover, there were no differ- } \\
\text { ences found between patients with type I } \\
\text { and type } 2 \text { Diabetes in study group. }\end{array}$ \\
\hline $\begin{array}{l}\text { Barghouti et al, } 2015{ }^{41} \\
\text { Jordan. }\end{array}$ & $\begin{array}{l}\text { Random selection, } 3196 \\
\text { (General population). }\end{array}$ & $\begin{array}{l}\text { Cross-sectional study. Knowledge and prac- } \\
\text { tice of leisure-time physical activity were } \\
\text { assessed by a questionnaire. }\end{array}$ & $\begin{array}{l}12.5 \% \text { were physically active, and } 55.9 \% \text { of } \\
\text { the participants recognised the recom- } \\
\text { mended physical activity guidelines in } \\
\text { Jordan. }\end{array}$ \\
\hline $\begin{array}{l}\text { Darawad et al, } 2016^{42} \\
\text { Four hospitals in } \\
\text { Jordan, Jordan. }\end{array}$ & $\begin{array}{l}\text { Convenience, II } 5 \\
\text { patients with diabetes. }\end{array}$ & $\begin{array}{l}\text { Cross-sectional survey. Exercise behaviours } \\
\text { were measured by patients' self-reported } \\
\text { questionnaires. }\end{array}$ & $\begin{array}{l}\text { An average number of } 3.2 \text { physical activities } \\
\text { per week (average of } 2.9 \text { hrs), with walking } \\
\text { being the most common activity. Lack of } \\
\text { desire, time, having diabetes were reasons } \\
\text { for not exercising. }\end{array}$ \\
\hline $\begin{array}{l}\text { Al Jamal and Ibrahim, } \\
201{ }^{43} \text { Al Mafraq } \\
\text { Governmental } \\
\text { Hospital in Jordan. }\end{array}$ & $\begin{array}{l}\text { Random selection, } 45 \\
\text { patients with T2DM and } \\
\text { I5 healthy participants. }\end{array}$ & $\begin{array}{l}\text { Pre/post randomised trial. Data about the } \\
\text { changes produced in the lipid profile after } \\
\text { consumption olive oil were collected by } \\
\text { asking participants to consume } 30 \mathrm{ml} \text { of } \\
\text { olive oil per day }\end{array}$ & $\begin{array}{l}\text { Four weeks of consumption of olive oil } \\
\text { lowered the levels of fasting blood glucose, } \\
\text { triglycerides, total cholesterol, and low } \\
\text { density lipoproteins in both groups. } \\
\text { Reduction was more profound in diabetics } \\
\text { than in healthy controls. }\end{array}$ \\
\hline $\begin{array}{l}\text { Jammal et al, } 2013 .{ }^{44} \\
\text { The National Diabetes } \\
\text { Centre and diabetes } \\
\text { clinic, Jordan. }\end{array}$ & $\begin{array}{l}\text { Random selection, } 127 \\
\text { patients with T2DM. }\end{array}$ & $\begin{array}{l}\text { Cross-sectional study. Data were collected } \\
\text { by complete ocular examinations }\end{array}$ & Prevalence of diabetic retinopathy of $7.9 \%$. \\
\hline $\begin{array}{l}\text { Abdel-Aal et al, } \\
2008 .^{45} \text { The National } \\
\text { Diabetes Centre, } \\
\text { Jordan. }\end{array}$ & $\begin{array}{l}\text { Convenience sampling, } \\
702 \text { patients with T2DM. }\end{array}$ & $\begin{array}{l}\text { Cross-sectional study. Data were collected } \\
\text { by reviewing medical records. }\end{array}$ & $\begin{array}{l}90 \% \text { of a sample of } 702 \text { patients with T2DM } \\
\text { had one or more types of dyslipidaemia in } \\
\text { Jordan. }\end{array}$ \\
\hline $\begin{array}{l}\text { Jarab et al, } 2018 .^{48} \text { The } \\
\text { Royal Medical Services } \\
\text { Hospital, Jordan. }\end{array}$ & $\begin{array}{l}\text { Purposive sampling, } 36 \\
\text { patients with T2DM. }\end{array}$ & $\begin{array}{l}\text { Qualitative study. Focus group method was } \\
\text { used to collect data about patients' per- } \\
\text { spective and experiences regarding T2DM. }\end{array}$ & $\begin{array}{l}\text { Medication regimen characteristics including } \\
\text { rout of administration, number of pre- } \\
\text { scribed medications and dosage frequency in } \\
\text { addition to perceived side effects repre- } \\
\text { sented the major barriers to medication } \\
\text { adherence. }\end{array}$ \\
\hline $\begin{array}{l}\text { Awwad et al, } 2015^{50} \\
\text { The University of } \\
\text { Jordan Hospital and } \\
\text { Jordan Hospital. }\end{array}$ & $\begin{array}{l}\text { Convenience sampling, } \\
902 \text { patients with chronic } \\
\text { conditions including } \\
\text { T2DM. }\end{array}$ & $\begin{array}{l}\text { Cross-sectional survey. Adherence to med- } \\
\text { icines using Morisky Medication Adherence } \\
\text { Scale (MMAS-8). }\end{array}$ & $\begin{array}{l}\text { Most of the participants had low adher- } \\
\text { ence. High income and higher education } \\
\text { were associated with higher adherence } \\
\text { scores. }\end{array}$ \\
\hline
\end{tabular}

(Continued) 
(Continued).

\begin{tabular}{|c|c|c|c|}
\hline $\begin{array}{l}\text { Author/s and } \\
\text { date }\end{array}$ & $\begin{array}{l}\text { Sample size and } \\
\text { characteristics }\end{array}$ & $\begin{array}{l}\text { Research design and methods of } \\
\text { data collection }\end{array}$ & Main findings \\
\hline $\begin{array}{l}\text { Basheti et al, } 2016^{51} \\
\text { Jordan. }\end{array}$ & $\begin{array}{l}\text { Random selection, } 167 \\
\text { patients with chronic } \\
\text { conditions. }\end{array}$ & $\begin{array}{l}\text { Cross-sectional survey. Adherence to med- } \\
\text { ications was assessed Morisky Medication } \\
\text { Adherence } \\
\text { Scale (MMAS-8). }\end{array}$ & $\begin{array}{l}46.1 \% \text { of participants were non adherent. } \\
\text { Patient adherence was positively affected by } \\
\text { older age, higher educational level, and } \\
\text { higher number of physician visits per month, } \\
\text { while it was negatively affected by reporting } \\
\text { difficulties with getting prescription refills on } \\
\text { time. }\end{array}$ \\
\hline $\begin{array}{l}\text { Al-Keilani et al, } 2017^{53} \\
18 \text { hospitals and health } \\
\text { care centres in Jordan. }\end{array}$ & $\begin{array}{l}\text { Convenience sampling, } \\
1079 \text { patients with } \\
\text { diabetes. }\end{array}$ & $\begin{array}{l}\text { Cross-sectional survey. Self-monitoring of } \\
\text { blood glucose (SMBG) adherence was mea- } \\
\text { sured by questionnaire. }\end{array}$ & $\begin{array}{l}59 \% \text { of participants were SMBG adherent. } \\
\text { Patients who were taking oral hypoglycemic } \\
\text { agents or insulin therapy tested more fre- } \\
\text { quently as compared to others. }\end{array}$ \\
\hline $\begin{array}{l}\text { Salayta and Aleyadeh, } \\
2010 .^{54} \text { King Hussein } \\
\text { Medical Centre, } \\
\text { Jordan. }\end{array}$ & $\begin{array}{l}\text { Convenience sampling, } \\
60 \text { patients with diabetes. }\end{array}$ & $\begin{array}{l}\text { Longitudinal cohort, prospective. Following } \\
\text { up } 60 \text { patients with a diabetic foot infection } \\
\text { to identify the progression of diabetic foot } \\
\text { infection }\end{array}$ & $\begin{array}{l}\text { Ten patients out of } 60(17 \%) \text { had below } \\
\text { knee amputation after failure of local foot } \\
\text { debridement. }\end{array}$ \\
\hline $\begin{array}{l}\text { Bakri et al, } 2012 . .^{55} \text { The } \\
\text { National Diabetes } \\
\text { Centre, Jordan. }\end{array}$ & $\begin{array}{l}\text { Random selection, } 1000 \\
\text { patients with diabetes. }\end{array}$ & $\begin{array}{l}\text { Cross-sectional survey. Data about the pre- } \\
\text { valence of diabetic foot ulcers were col- } \\
\text { lected by reviewing the medical records, } \\
\text { interviewing, and examining the patients. }\end{array}$ & $\begin{array}{l}\text { Diabetic foot ulcer prevalence was } 4.6 \% \text {, } \\
\text { sensory neuropathy } 14.9 \% \text {, lower limb } \\
\text { ischemia } 7.5 \% \text {, and amputation } 1.7 \% \text {. }\end{array}$ \\
\hline $\begin{array}{l}\text { Al-Sahouri et al, } \\
2019 .^{56} \\
\text { Comprehensive health } \\
\text { care centre, Jordan. }\end{array}$ & $\begin{array}{l}\text { Purposeful sampling, } 38 \\
\text { patients with T2DM. }\end{array}$ & $\begin{array}{l}\text { Qualitative study. Attitudes, perceptions and } \\
\text { knowledge of patients were explored by } \\
\text { a focus group method. }\end{array}$ & $\begin{array}{l}\text { Patients reported the different ways in } \\
\text { which they were diagnosed with Type } 2 \\
\text { diabetes. Stress and family history were } \\
\text { perceived as causes of developing diabetes } \\
\text { and reasons for poorly controlled diabetes. } \\
\text { Patients' responses also showed a poor } \\
\text { understanding of the basic knowledge of } \\
\text { diabetes. }\end{array}$ \\
\hline $\begin{array}{l}\text { Abu-Qamar and } \\
\text { Wilson, 2011.57 Six } \\
\text { hospitals throughout } \\
\text { Jordan }\end{array}$ & $\begin{array}{l}\text { Purposeful sampling, } 7 \\
\text { patients with diabetes. }\end{array}$ & $\begin{array}{l}\text { Qualitative. Patient's views of diabetic foot } \\
\text { care within the Jordanian healthcare system } \\
\text { were collected by unstructured interviews. }\end{array}$ & $\begin{array}{l}\text { Participants were not practising preventive } \\
\text { foot care behaviours. Participants believed } \\
\text { that the presence of diabetes does not } \\
\text { necessitate the need for regular foot exam- } \\
\text { ination when there are no active ulcers on } \\
\text { their feet. }\end{array}$ \\
\hline $\begin{array}{l}\text { Wazaify et al, } 2013 .^{70} \\
\text { Jordan University } \\
\text { Hospital, Jordan. }\end{array}$ & $\begin{array}{l}\text { Random selection, } 700 \\
\text { patients with chronic } \\
\text { conditions including } \\
\text { T2DM. }\end{array}$ & $\begin{array}{l}\text { Cross sectional study. The prevalence of } \\
\text { herbal medicine use was explored by a semi- } \\
\text { structured questionnaire. }\end{array}$ & $\begin{array}{l}7.6 \% \text { of a sample reported using herbs. Most } \\
\text { of complementary and alternative medicine } \\
\text { users were older than } 50 \text { years of age and } \\
\text { predominantly female. }\end{array}$ \\
\hline $\begin{array}{l}\text { Wazaify et al, } 2011^{71} \\
\text { National Diabetes } \\
\text { Centre, Jordan. }\end{array}$ & $\begin{array}{l}\text { Random selection, } 1000 \\
\text { patients with diabetes. }\end{array}$ & $\begin{array}{l}\text { Cross sectional study. Data about preva- } \\
\text { lence, type, frequency, purpose and pattern } \\
\text { of herbal preparation were collected by } \\
\text { a semi-structured questionnaire. }\end{array}$ & $\begin{array}{l}16.6 \%(n=166) \text { of a sample of } 1000 \text { patients } \\
\text { with diabetes, were users of herbal reme- } \\
\text { dies in Jordan and green tea was the most } \\
\text { popular herb used by participants. }\end{array}$ \\
\hline
\end{tabular}




\section{Publish your work in this journal}

Patient Preference and Adherence is an international, peer-reviewed, open access journal that focusing on the growing importance of patient preference and adherence throughout the therapeutic continuum. Patient satisfaction, acceptability, quality of life, compliance, persistence and their role in developing new therapeutic modalities and compounds to optimize clinical outcomes for existing disease states are major areas of interest for the journal. This journal has been accepted for indexing on PubMed Central. The manuscript management system is completely online and includes a very quick and fair peer-review system, which is all easy to use. Visit http:// www.dovepress.com/testimonials.php to read real quotes from published authors. 